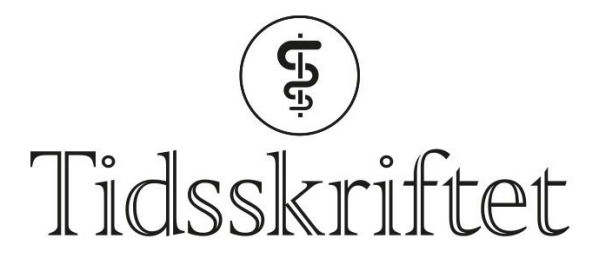

DEN NORSKE LEGEFORENING

\title{
Om vanskelige luftveier og nødlandinger
}

KRONIKK

\section{LARS PRAG ANTONSEN}

E-post: larspantonsen@hotmail.com Lars Prag Antonsen (f. 1980) er lege i spesialisering i anestesi ved Sykehuset Østfold og ved Oslo universitetssykehus, Ullevål.

Forfatter har fylt ut ICMJE-skjemaet og oppgir ingen interessekonflikter.

Er medisinske beslutninger kun basert på fakta?Bør vi fortsette jakten på prosedyrerog algoritmer, eller stole mer på egen erfaring og kompetanse? Beslutningsteoretisk innsikt kan bidra med svar på disse spørsmålene.

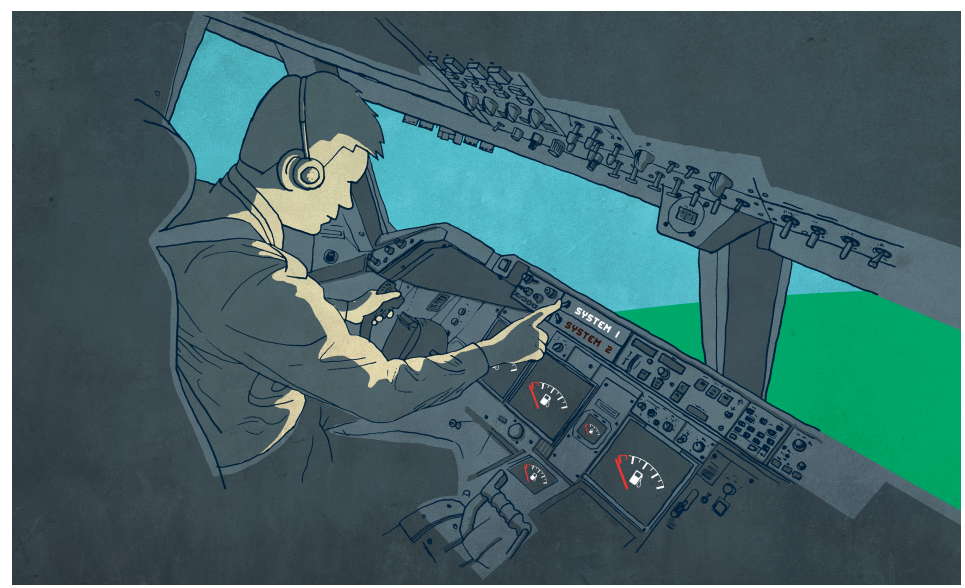

Illustrasjon: Ørjan Jensen/Superpop

Ansvaret for å ta beslutninger er en sentral del av legeyrket. Alle leger har kjent på usikkerheten knyttet til krevende avgjørelser. Slik bør det være. Det er et ansvar vi må ønske å ha.

Noen fagfelt - som anestesi og traumatologi - er preget av tidskritiske ja/nei-beslutninger som må tas hurtig og på sviktende informasjonsgrunnlag. I andre fagfelt, for eksempel rehabilitering, er usikkerheten knyttet til komplekse og langvarige beslutningsprosesser over uker og måneder.

Tradisjonelt har vi vært flinke til å vektlegge oppdatert faglig kunnskap om diagnostikk og behandling. Når vi opplever feil og avvik, er løsningen ofte å søke mer kunnskap og/eller utarbeide nye retningslinjer og prosedyrer.Dette er viktige og riktige forutsetninger for god medisinsk praksis, men bare en del av løsningen.

Her vil jeg belyse temaet fra en annenvinkel: Hvordan kaninnsikt i beslutningsteori gjøre 
oss til bedre beslutningstagere? To forskere har vært - og er fortsatt - sentrale innen feltet: Nobelprisvinner og psykolog Daniel Kahnemaner for mange best kjent som forfatter av bokenThinking, fast andslow (1). Hanhar vært viktig for utviklingen av modellen Heuristics andbiases approach. Psykolog og forskerGary Klein har vært ledende i arbeidet med teorienomRecognition-primed decisionmaking (2).

\section{Kahnemans kognitive feilkilder}

Ifølge Kahneman benytterhjernen to ulike systemer når den tar beslutninger (1). System 1 tarraske og automatiske avgjørelser uten vår bevisste innsats.Vi oppfatter intuitivt en kjent stemme, et aggressivt ansikt eller enkle tallverdier på en monitor uten at dette krever fokusert mental innsats. Dette er system 1 som automatisk tar beslutninger basert på kjente mønstre, avstander og lyder.System 2jobber saktere, men mer analytisk. Det gjør oss i stand til å resonnere og reflektere, som når vi forsøker å trekke konklusjoner basert på store mengder informasjon. Bruk av system 2 krever konsentrasjon og bevisst innsats.

Begge systemene har sine styrker, svakheter og feilkilder. Kahneman (1), Lighthall (3) og Stiegler (4) presentereren rekke tankevekkende eksempler på hvor feilbarlig en beslutningsprosess kan være. Den fiktive historien under er basert på sistnevntes artikkel:

En anestesilege gjør preoperativt tilsyn på en jente før appendektomi. Hun er ellers frisk, men jentas mor mener å huske at anestesilegen kanskje hadde sagt det var vanskelig å intubere da hun ble tonsillektomert for noen år siden.Anestesilegen ser ingen kliniske tegn til vanskelige luftveier, og det står ingen ting i journalen. Det er flere år siden hun ble operert sist, og han tenker at forholdene nok har endret seg.Anestesilegen holder seg til planen og tenker at det som regel går greit. Jentas far - som er advokat - spøker med at han skal lage bråk om det blir noe tull og mumler noe om et stort avisoppslag nylig.Anestesilegen tenker seg om igjen og spør en kollega om assistanse under narkoseinnledningen, men kollegaen er opptatt. Videolaryngoskopene er i bruk. Kirurgen maser om å komme i gang, og anestesilegen starter litt motvillig mens han forsikrer seg selv om at han har løst tilsvarende situasjoner fint tidligere. Heldigvis går alt bra, og anestesilegen er fornøyd med egen vurdering og innsats. Kollegene er derimot skeptiske til at han ikke bremset og tok høyde for større luftveisutfordringer.

Historien illustrerer flere godt dokumenterte psykologiske effekter som påvirker en beslutningsprosess (4): Vi ser ofte etter informasjon som bekrefter det vi vet, og vi overser motstridende opplysninger (bekreftelsesbias). Vi forankres dessuten i vår opprinnelige plan og klarer i liten grad å revurdere (forankringsbias). Videre påvirker ressurssterke pasienter og pårørende oss i større grad enn andre (glorieeffekt). Sannsynlighet og risiko bedømmes ut fra hvor lett vi husker andre hendelser (tilgjengelighetsbias). Vi tar unødig risiko for å unngå å fremstå som inkompetente (tapsaversjon), samtidig som vi i liten grad er bevisst hvilke feilkilder som påvirker oss (blindflekkbias). Ofte vurderer vi identisk informasjon annerledes retrospektivt (etterpåklokskap).

Det er identifisert en lang rekke slike kognitive feilkilder, og det erutviklet forslag til mentale strategier for å motvirke effektenav dem (1-4). Ifølge Stiegler må vi derfor erkjenne at kliniske beslutningsprosesser er preget av kognitive feilkilder, individuelle preferanser og unøyaktige sannsynlighetsberegninger selv når diagnosen er kjent og det foreligger retningslinjer for behandling. Det betyr at faglig kunnskap er sentralt, men også feilbarlig. Dette gjelder særlig under tidspress, usikkerhet og når man er sliten (4). Kahneman og hans tilhengere bruker dette som argument for atprosedyrer og retningslinjer er viktige i en beslutningsprosess nettopp fordi vi lett lar oss lure av disse kognitive feilkildene (1).

\section{Kleins intuisjon}

Klein hevder at erfarne utøvere av et fag i stor grad tar beslutninger basert på erfaring og mønstergjenkjenning (2). En ekspert gjenkjenner mønstre og elementer i nye situasjoner og sammenligner dette med tidligere erfaringer. Ulike løsninger simuleres mentalt inntil han 
eller hun finner en som kan tenkes å fungere. Det foregår i liten grad bevisst sammenligning av ulike hypoteser. Dette kan forklare hvorfor erfarne fagfolk i kritiske situasjoner knapt er bevisst hvordan de tenkte for å komme frem til løsningen.

Kleins modell er utviklet gjennom studier av blant annet brannmenn, militært personell og andre profesjoner der beslutningsprosessene er preget av dårlig tid, usikkerhet oguforutsigbare omgivelser (2).

Klein anerkjenner at menneskelig erfaring og dømmekraft er feilbarlig slik Kahnemans forskning viser, men påpeker at disse feilkildene også - eller kanskje først og fremst - er mentale snarveier som setter oss i stand til å ta hurtige beslutninger.Han vektlegger erfaring og mønstergjenkjenning som viktige faktorer i en beslutningsprosess ogadvarer mot troen på at prosedyrer kan erstatte erfaring i komplekse og uoversiktlige situasjoner (2).

IbokenStreetlightsandshadows:searchingforthekeysto adaptivedecisionmaking (2) beskriver Klein hvordan kaptein Bob Pearson og hans styrmannsitterbak spakene i en Boeing 767 over Canada23. juli 1983. Plutselig stopper drivstoffpumpentil den venstre motoren. Kaptein Pearson blir ikke nevneverdig bekymret. Han kjenner prosedyrene for en slik feil. Ikke lenge etter stopper venstre motor. Kapteinen holder hodet kaldt og planlegger nødlanding. Han har solide prosedyrer for slike situasjoner. Han rekker knapt å åpnesjekklistenfør også høyre motor stanser. Og som for å understreke alvoret, forsvinner alt lys i cockpiten. De to flygerne ser på hverandre og innser at det umulige har skjedd. De sitter i en stor flymaskin med 61 passasjerer 41 ooo fot over bakken - og de er tomme for drivstoff. Kapteinen innser at han er i enhelt ny situasjon og at han ikke har noen prosedyrer å støtte seg på. Derimot har han mange års erfaring som flyger, også som glideflyger. Etter noen intense minutter står flyet trygt på bakken. Ingen passasjerer er skadet, flyet blir reparert og er på ny i luften to dager senere. Flyet og hendelsen fikk navn etter flyplassende landet på:TheGimliGlider.

Klein og tilhengerne av hans modell bruker denne og lignende historier som dramatiske og viktige påminnelser omatdet er umulig å lage prosedyreverk som dekker alle tenkelige eventualiteter.Når situasjonens kompleksitet øker, kan ingenting erstatte erfaring og høy kompetanse (2).

\section{Kleinversus Kahneman}

Så hvordan skal vi forholde oss til disse to tilsynelatende motstridende modellene? Kahneman legger vekt på at man selv med god fagkunnskap og erfaring er svært påvirkelig av kognitive feilkilder. Klein vektlegger nettopp erfaring og mønstergjenkjenning som viktige faktorer i en beslutningsprosess.

Svaret gir deto forskerne selv i artikkelenConditionsfor intuitiveexpertise: afailuretodisagree (5). Hovedbudskapet er at teoriene utfyller hverandre mer enn de motsier hverandre. En helhetlig tilnærming til gode beslutninger inkluderer både prosedyrer, retningslinjer og klinisk erfaring. Både intuitive og analytiske strategier har sine styrker og svakheter. Den optimale beslutningsstrategien vil avhengeblant annetav legens kompetanse- og erfaringsnivå, situasjonens karakter og hastegrad samt tilgjengelig utstyr. Utfordringen ligger i å ha tilstrekkelig mental fleksibilitettil å velge riktig strategibasert på situasjonen som foreligger.

\section{Kan beslutningskompetanseøves?}

Det er vanskelig å forske på hvordan mennesker tar beslutninger i reelle situasjoner preget av usikkerhet, tidspress og manglende informasjon. Forsøk på å dekonstruere en slik kompleksitet overforenkler den virkeligheten man ønsker å studere. Derfor foreligger det heller ikkeoverbevisende evidens på hvorvidt beslutningskompetanse kan øves. Til tross for manglende kunnskapsgrunnlag virker det rimelig å anta at slik øving har effekt.

Eksempelvis har flybransjen og operative militære avdelinger lenge vektlagt

beslutningsdyktighet som en sentral ferdighet (1-6). 
I medisinsk sammenheng erdet foreslått at slik opplæring kan bestå av undervisning $\mathrm{i}$ teoretisk kunnskap, kombinertmed simulering og, viktigst, implementering i daglig virksomhet $(3,4)$.

En grunnleggendeteoretiskforståelseav beslutningsteori består i å kjenne viktige modeller for hvordan mennesker tar beslutninger, hvilke feilkilder som påvirker oss, og hvordan vi kan motvirke disse.Teoretisk forståelse kan opparbeides gjennom egenstudier av relevant litteratur, diskusjon med kolleger og/eller ulike former undervisning - gjerne allerede under medisinstudiene $(3,4)$. Dette vil giet felles rammeverk av begreper og definisjoner.

Simulering og øvelserhar fått en viktig plass i medisinsk utdanning. Det finnesutdanningsmodeller som, i tillegg til det rent fagmedisinske, er ment å øve kognitive strategier spesifikt (6). Simuleringssituasjonen bør foregå i et miljø som tilsvarer det man vanligvis jobber i, og med de samme menneskene. Kasuistikkene og tilbakemeldingene bør problematisere temaer som hvordan klinisk informasjon oppfattes, overses og prioriteres. Dette stimulerer til bevisste veivalg og til metakognisjon: Hvorfor tenker jeg slik jeg gjør (6).

Implementering iklinisk arbeid kan løses med ulike virkemidler, og organiseringen av daglig drift bør legge til rette for til dette. Selvmonitorering bidrar til å gjenkjenne feilkilder i egne beslutningsprosesser og til å anvende kognitive strategier for å minimere betydningen av dem. Dette kanavverge potensielt farlige situasjoner før de oppstår.Forståelse for, og erfaring med, at tidspress og mangel på informasjon er normaltilstanden kan bidra til å redusere frustrasjon og følelse av utilstrekkelighet.Gode rutiner for kontinuerlig og direkte tilbakemelding på effekten av egnevurderinger er en forutsetning for utvikling av ekspertise.Klein og Kahneman kaller dette et miljø med høy validitet (5).

Beslutningsteoretiske begreper kan bidra til presis kommunikasjon i akutte problemstillinger og når vi retrospektivt bedømmer hverandres avgjørelser og forsøker å analysere beslutningsgrunnlaget for disse. Særlig gjelder dette ved håndteringen av sjeldne og/eller uønskede hendelser. Det er dermed viktig som verktøy i arbeid med kvalitetsforbedring.

Vi bør anvende og videreutvikle prosedyrer for situasjoner der forutsetningene ligger til rette for det. Prosedyrer er godt egnet ved sykdomsforløp der pasientens symptomer er avgrenset og behandlingsmålet definert. Slike prosedyrer kan sikre at pasienter kommer hurtig til korrekt behandling ved akutt hjerteinfarkt eller får blodsukkeret gradvis korrigert ved diabetes ketoacidose. Gode algoritmer bidrar til effektive mottak av traumepasienter, og sjekklister minimerer forglemmelser.

Prosedyrer er en god start for nybegynnere, men bør ikke være en begrensende faktor for den erfarne som ser smidigere løsninger. Samtidig bør vi unngå prosedyrebasert praksis der det er uhensiktsmessig (5). Prosedyrer er ofte uegnet i komplekse situasjoner. Streng prosedyretenkning kan senke aktsomhet og faglig interesse hos medarbeidere-og dermed virke mot sin hensikt over tid (5). Ingen prosedyresamling kan favne alle eventualiteter. En alvorlig syk pasient med lang sykehistorie, uklare symptomer og dårlig definert behandlingsmål kan ikke behandles ved å følge et flytskjema. Akkurat like lite som en flyger rekker å slå opp i prosedyresamlingen for å lande et fly uten drivstoff.

Resultatet er beslutningsdyktige leger, robuste beslutningerogbedre pasientbehandling.

\footnotetext{
LITTERATUR:

1. Kahneman D. Thinking, fast and slow. New York, NY: Farrar, Straus and Giroux, 2011.

2. Klein G. Streetlights and shadows: searching for the keys to adaptive decision making. Cambridge, MA: The MIT Press, 2009.

3. Lighthall GK, Vazquez-Guillamet C. Understanding decision making in critical care. Clin Med Res
} 
2015; 13: 156 - 68. [PubMed][CrossRef]

4. Stiegler MP, Tung A. Cognitive processes in anesthesiology decision making. Anesthesiology 2014; 120: 204 - 17. [PubMed][CrossRef]

5. Kahneman D, Klein G. Conditions for intuitive expertise: a failure to disagree. Am Psychol 2009; 64: 515-26. [PubMed][CrossRef]

6. Klein G, Wright C. Macrocognition: from theory to toolbox. Front Psychol 2016; 7: 54.

[PubMed][CrossRef]

Publisert: 2. oktober 2017. Tidsskr Nor Legeforen. DOI:10.4045/tidsskr.17.0558

Mottatt 27.6.2017, første revisjon innsendt 16.8.2017, godkjent 22.8.2017.

(C) Tidsskrift for Den norske legeforening 2020. Lastet ned fra tidsskriftet.no 